\title{
Effect of Vasopressin and its Analogs versus Catecholamines on the Renal Outcomes in Septic Shock:A Systematic Review and Meta-Analysis of Randomized Trials
}

\section{Amina Elmi Yusuf}

Nanjing Medical University Second Affiliated Hospital https://orcid.org/0000-0003-0030-1746

Wei He

Nanjing Medical University Second Affiliated Hospital

\section{Rongjie YU}

Nanjing Medical University Second Affiliated Hospital

Liqun Sun ( $\nabla$ njuslq@163.com )

Second Affiliated Hospital of Nanjing Medical University https://orcid.org/0000-0003-3524-8543

\section{Research}

Keywords: Acute kidney injury, Renal replacement therapy, Catecholamines, Vasopressin, Septic shock.

Posted Date: August 23rd, 2021

DOl: https://doi.org/10.21203/rs.3.rs-779297/v1

License: () This work is licensed under a Creative Commons Attribution 4.0 International License. Read Full License 


\section{Abstract}

Background: This current systematic review and meta-analysis aimed to evaluate the association of Vasopressin and its analogs and adverse renal outcomes compared to Catecholamines in adult patients with septic shock.

Method: We performed a systematic review of the literature published from inception to March 31, 2021, using online databases of PubMed, Embase, Cochrane Library. Randomized controlled trials reporting any renal function and comparing Vasopressin and its analogs with Catecholamines among adult septic shock patients. Our primary outcomes relating to acute renal failure were acute kidney injury incidence and the need for Renal replacement therapy. Our secondary outcomes were three: Renal replacement therapy free-days and 48h postadministration change in creatinine level and urine output. We applied a fixed-effects model to estimate the risk ratio (RR) for (dichotomized outcomes) and standard mean difference (SMD) for (continues outcomes).

Results: 18 trials met the inclusion criteria with a total of 4,024 patients. 13 studies were eligible for quantitative meta-analysis and 5 studies were eligible for qualitative data. For the primary outcome, Vasopressin or its agonist are associated with a lower $\mathrm{AKI}$ incidence (Risk ratio $0.93,95 \% \mathrm{Cl}[0.86,1.00], \mathrm{P}=0.04, \mathrm{I}^{2}=5 \%$ ) and a reduced need for renal replacement therapy (Risk ratio $0.84,95 \% \mathrm{Cl}[0.73,0.97], \mathrm{P}=0.02, \mathrm{I}^{2}=11 \%$ ). We found no statistical significance in the pooled estimates for the secondary outcomes: RRT free-days (28 or 30 days) ( $P$ $\left.=0.65, \mathrm{I}^{2}=0 \%\right), 48 \mathrm{~h}$ creatinine level $\left(\mathrm{P}=0.81, \mathrm{I}^{2}=39 \%\right)$, and $48 \mathrm{~h}$ urine output $\left(\mathrm{P}=0.46, \mathrm{I}^{2}=8 \%\right)$.

Conclusions: Vasopressin and its analogs are associated with a reduced AKI incidence and a lower RRT use rate in septic shock compared to catecholamines. Furthermore, we did not find a significant effect of Vasopressin on the number of RRT- free days (up to 28 or 30 days) or in creatinine level and urinary output in 48 hours. However, due to the high mortality associated with S-AKI, large blinded RCTs addressing renal function impairment in septic shock are warranted.

\section{Introduction:}

Septic shock is considered one of the most common causes of intensive care unit admission, and despite all new improvements in sepsis management, it continues to be one of the leading causes of Intensive Care Unit (ICU) mortality (1-3). Norepinephrine is the suggested first-line vasopressor in septic shock by The Surviving Sepsis Campaign (SSC) guideline, and it is often the first line of choice as a vasopressor because of its reliable effectiveness to achieve an adequate MAP in septic shock patients (4-7).

However, Norepinephrine has several adverse effects at high doses, including increased tissue oxygen demand, excessive vasoconstriction leading to decreased renal and mesenteric blood flow, increased pulmonary vascular resistance, alteration of the immune response, and coagulation (8-10). Notably, over a short time, a substantial number of patients become refractory to Norepinephrine, and vascular responsiveness to catecholamines like Norepinephrine diminishes, thus requiring increased doses, hence increasing the risk of side effects $(11,12)$. Vasopressin, an endogenous peptide hormone produced by the hypothalamus and stored in the pituitary gland, has emerged as an adjunct to catecholamines. Vasopressin is relatively deficient during septic shock because of the depletion of vasopressin store from the pituitary gland and inhibition of synthesis and release (13). 
Renal function impairment is a frequent complication of severe sepsis, and it is associated with high mortality $[18,19]$ with an incidence of Sepsis-Acute kidney injury (S-AKI) ranging from 55 to $73 \%(14-18)$. Previous studies have demonstrated the beneficial effects of Vasopressin and analogs on renal function. Increased creatinine clearance, higher urinary output, lower acute kidney injury (AKI) incidence, and a reduced need for renal replacement therapy (RRT) in patients with septic shock treated with Vasopressin compared to other vasopressors were reported (19-26). However, definitive evidence analyzing the data only on patients with septic shock is lacking.

Therefore, the objective of this present study was to evaluate the association of Vasopressin and its analogs compared to Catecholamines alone on the reduction of adverse renal outcomes in adult patients with septic shock.

\section{Methodology:}

Our review and meta-analysis was performed in accordance to the 2020 preferred reporting items for Systematic reviews and Meta-analysis (PRISMA) statement (27).

\section{Eligibility criteria}

The study must evaluate adult patients at least 18 years of age with septic shock and must be randomized controlled trials. Included studies must compare the administration of Vasopressin or analogs with or without concomitant of Catecholaminergic vasopressors vs. administration of Catecholaminergic vasopressors alone, or placebo irrespective of dose, duration, or co-intervention. Reports at least one renal outcome related to acute renal failure, e.g., AKI incidence, and the need for RRT, RRT-free days, urine output, or creatinine level. We complied with the original authors' definitions of each of these endpoints.

The exclusion criteria were: age $<18$ years, Case reports, letters, comments, duplicate publications, reviews, case-control studies, cohort studies, or animal studies.

\section{Information source and search strategy}

We conducted a comprehensive electronic search using various (MeSH) terms like "septic shock," "Arginine Vasopressin," "Vasopressin," "Sepsis." The following electronic databases were searched PubMed, Embase, and Cochrane Library databases. Relevant studies in databases were searched from their inception up to March 31, 2021. The search strategy for PubMed is described in (Additional file 1).

\section{Study selection process}

Trials selection was done by two reviewers (WH, and RY) independently. We set no language restrictions. Full papers of the potentially eligible studies were retrieved. The same two reviewers then independently screened full texts in duplicate and recorded the main reason for exclusion. Any discrepancy was solved by discussion until consensus was reached or discussion with a third reviewer. The reference data of retrieved publications were manually searched for potentially relevant bibliographies of studies.

\section{Data collection process}


Two reviewers (WH and RY) independently extracted data using a predesigned form. The primary outcomes were acute kidney injury incidence and the need for renal replacement therapy. The secondary outcomes were renal replacement therapy Free-days (28 or 30 days), 48h Creatinine level, and $48 \mathrm{~h}$ urine output. The data about the studies were recorded according to the first author, year of publication, study design, clinical setting, the total number of participants, type of intervention, and the number of events in each group for each of the assessed outcomes. Similarly, any disagreements were resolved by discussion until consensus was reached.

\section{Study quality and risk of bias assessment}

To assess the risk of bias of included studies, in each trial, the review authors (AEY, WH) assessed by using the Cochrane Risk of Bias Tool Version 5.4. The following domains were evaluated: sequence generation, allocation concealment, blinding, incomplete outcome data, selective reporting, and other sources of bias. The risk of bias was labeled as high, unclear, or low.

\section{DATA SYNTHESIS AND ANALYSIS}

All statistical analyses were performed using Review Manager Version 5.3 (Nordic Cochrane Center, Copenhagen, Denmark). For Dichotomous data, we expressed the pooled effect estimates using the risk ratio (RR) of each study using the number of events on each arm if data were available as absolute numbers. In contrast, mean differences (MD) were used for pooling continuous data. The pooled results were calculated with $95 \%$ confidence intervals $(\mathrm{Cl})$. A non-significant chi-square test result (a $p$-value $\geq$ of 0.1 and an 12 value $\leq$ of $50 \%$ ) only suggested that there was no evidence of heterogeneity. A fixed-effects model with MantelHaenszel weighting was used for all analyses. Publication bias was evaluated using funnel plots of the primary endpoint by visually inspecting publication bias and small-study effects.

\section{Results:}

\section{Study Selection}

The electronic search yielded 2040 relevant studies in total for further assessment. There were no additional studies identified by hand searching reference list that were not already found in the electronic search. After removing duplicates and complete screening of reference based on titles and abstract, and text screening, 18 trials met our inclusion criteria and were eligible for final analysis, 13 trials for quantitative analysis, and five trials for qualitative analysis. (See Fig. 1) for study selection and exclusion flowchart.

\section{Studies and patients' characteristics}

The 18 trials reported on 4,024 septic shock patients. The number of patients included in these randomized controlled trials ranged from 10 to 828. The included trials were published from 1999 to 2019. Eight studies were double-blind, nine were open-label, and one was single-blind. Eight enrolled trials were designed as multicenter studies, and one study was published in conference abstract form (28). Thus, further details were not available for this review. All included studies characteristics are presented in (Table 1).

2,179 subjects received Vasopressin or analogs as the study group, and 1,825 received catecholamine mainly (Norepinephrine) as the control group. The AKI definition varied among the included trials. Only One study 
considered the renal outcome (AKI free-days) as the primary outcome. Vasopressin and Terlipressin dosage and administration varied between trials. Vasopressin was administered in 10 studies and Terlipressin in 6 studies.

One study used both Vasopressin and Terlipressin, and one study used Selepressin as the vasopressor of choice. Evaluated renal outcomes for the included trials are described in (Additional file 2). 
Table 1

characteristics of the included randomized trials.

\begin{tabular}{|c|c|c|c|c|c|c|c|}
\hline Source & design & center & setting & $\begin{array}{l}\text { Number } \\
\text { of } \\
\text { patients }\end{array}$ & Condition & $\begin{array}{l}\text { Treatment } \\
\text { Group }\end{array}$ & $\begin{array}{l}\text { Comparison } \\
\text { Group }\end{array}$ \\
\hline $\begin{array}{l}\text { Malay et } \\
\text { al,1991 } \\
(29)\end{array}$ & $\begin{array}{l}\text { Double- } \\
\text { blind }\end{array}$ & $\begin{array}{l}\text { Single } \\
\text { center }\end{array}$ & ICU & 10 & $\begin{array}{l}\text { Septic } \\
\text { shock }\end{array}$ & Vasopressin & Catecholamine \\
\hline $\begin{array}{l}\text { Patel et al, } \\
2002 \text { (30) }\end{array}$ & $\begin{array}{l}\text { Double- } \\
\text { blind }\end{array}$ & $\begin{array}{l}\text { Multi } \\
\text { center }\end{array}$ & ICU & 24 & $\begin{array}{l}\text { Septic } \\
\text { shock }\end{array}$ & Vasopressin & Norepinephrine \\
\hline $\begin{array}{l}\text { Dunser et } \\
\text { al, } \\
2003(31)\end{array}$ & $\begin{array}{l}\text { Open } \\
\text { label }\end{array}$ & $\begin{array}{l}\text { Single } \\
\text { center }\end{array}$ & ICU & 48 & $\begin{array}{l}\text { Vasodilatory } \\
\text { Shock } \\
\text { including } \\
\text { septic } \\
\text { shock, } \\
\text { sepsis, and } \\
\text { cardiotomy }\end{array}$ & Vasopressin & Norepinephrine \\
\hline $\begin{array}{l}\text { Albanese } \\
\text { et el, } 2005 \\
(32)\end{array}$ & $\begin{array}{l}\text { Open } \\
\text { label }\end{array}$ & $\begin{array}{l}\text { Single } \\
\text { center }\end{array}$ & ICU & 20 & $\begin{array}{l}\text { Septic } \\
\text { shock }\end{array}$ & Terlipressin & Norepinephrine \\
\hline $\begin{array}{l}\text { Lauzier et } \\
\text { al, } 2006 \\
(33)\end{array}$ & $\begin{array}{l}\text { Open } \\
\text { label }\end{array}$ & $\begin{array}{l}\text { Multi } \\
\text { center }\end{array}$ & ICU & 23 & $\begin{array}{l}\text { Septic } \\
\text { shock }\end{array}$ & $\begin{array}{l}\text { Arginine } \\
\text { Vasopressin }\end{array}$ & Norepinephrine \\
\hline $\begin{array}{l}\text { Morelli et } \\
\text { al, } 2008 \\
(34)\end{array}$ & $\begin{array}{l}\text { Open } \\
\text { label }\end{array}$ & $\begin{array}{l}\text { Multi } \\
\text { center }\end{array}$ & ICU & 59 & $\begin{array}{l}\text { Septic } \\
\text { shock }\end{array}$ & $\begin{array}{l}\text { Terlipressin + } \\
\text { Norepinephrine } \\
\text { Terlipressin + } \\
\text { Dobutamine + } \\
\text { Norepinephrine }\end{array}$ & Norepinephrine \\
\hline $\begin{array}{l}\text { Russell et } \\
\text { el, 2008 } \\
\text { (35) }\end{array}$ & $\begin{array}{l}\text { Double- } \\
\text { blind }\end{array}$ & $\begin{array}{l}\text { Multi } \\
\text { center }\end{array}$ & ICU & 779 & $\begin{array}{l}\text { Septic } \\
\text { shock and } \\
\text { cirrhosis }\end{array}$ & Vasopressin & Norepinephrine \\
\hline $\begin{array}{l}\text { Morelli et } \\
\text { el, 2009 } \\
(36)\end{array}$ & $\begin{array}{l}\text { Open } \\
\text { label }\end{array}$ & $\begin{array}{l}\text { Single } \\
\text { center }\end{array}$ & ICU & 45 & $\begin{array}{l}\text { Septic } \\
\text { shock }\end{array}$ & $\begin{array}{l}\text { Vasopressin Or } \\
\text { Terlipressin }\end{array}$ & Norepinephrine \\
\hline $\begin{array}{l}\text { Acevedo et } \\
\text { el, } 2009 \\
(28)\end{array}$ & $\begin{array}{l}\text { Open } \\
\text { label }\end{array}$ & Unclear & ICU & 24 & $\begin{array}{l}\text { Septic } \\
\text { shock and } \\
\text { cirrhosis }\end{array}$ & Terlipressin & $\begin{array}{l}\text { Alpha } \\
\text { adrenergic } \\
\text { drugs }\end{array}$ \\
\hline $\begin{array}{l}\text { Acevedo et } \\
\text { el, } 2009 \\
(28)\end{array}$ & $\begin{array}{l}\text { Open } \\
\text { label }\end{array}$ & Unclear & ICU & 24 & $\begin{array}{l}\text { Septic } \\
\text { shock and } \\
\text { cirrhosis }\end{array}$ & Terlipressin & $\begin{array}{l}\text { Alpha } \\
\text { adrenergic } \\
\text { drugs }\end{array}$ \\
\hline $\begin{array}{l}\text { Gordon et } \\
\text { el, } 2010 \\
(20)\end{array}$ & $\begin{array}{l}\text { Double- } \\
\text { blind }\end{array}$ & $\begin{array}{l}\text { Multi } \\
\text { center }\end{array}$ & ICU & 779 & $\begin{array}{l}\text { Septic } \\
\text { shock }\end{array}$ & Vasopressin & Norepinephrine \\
\hline $\begin{array}{l}\text { Barzegar } \\
\text { et al, } 2016 \\
\text { (37) }\end{array}$ & $\begin{array}{l}\text { Open } \\
\text { label }\end{array}$ & $\begin{array}{l}\text { Single } \\
\text { center }\end{array}$ & ICU & 30 & $\begin{array}{l}\text { Septic } \\
\text { Shock }\end{array}$ & $\begin{array}{l}\text { Arginine } \\
\text { Vasopressin }\end{array}$ & Norepinephrine \\
\hline
\end{tabular}

ICU- intensive care unit 


\begin{tabular}{|llllllll|}
\hline Source & design & center & setting & $\begin{array}{l}\text { Number } \\
\text { of } \\
\text { patients }\end{array}$ & Condition & $\begin{array}{l}\text { Treatment } \\
\text { Group }\end{array}$ & $\begin{array}{l}\text { Comparison } \\
\text { Group }\end{array}$ \\
\hline $\begin{array}{l}\text { Xiao et el, } \\
2016(24)\end{array}$ & $\begin{array}{l}\text { Single } \\
\text { blind }\end{array}$ & $\begin{array}{l}\text { Single } \\
\text { center }\end{array}$ & ICU & 32 & $\begin{array}{l}\text { Septic } \\
\text { shock }\end{array}$ & Terlipressin & Norepinephrine \\
\hline $\begin{array}{l}\text { Gordon et } \\
\text { el, 2016 } \\
\text { (25) }\end{array}$ & $\begin{array}{l}\text { Double- } \\
\text { blind }\end{array}$ & $\begin{array}{l}\text { Multi } \\
\text { center }\end{array}$ & ICU & 421 & $\begin{array}{l}\text { Septic } \\
\text { shock }\end{array}$ & Vasopressin & Norepinephrine \\
$\begin{array}{l}\text { Choudhury } \\
\text { et el, 2017 } \\
\text { (19) }\end{array}$ & $\begin{array}{l}\text { Open } \\
\text { label }\end{array}$ & $\begin{array}{l}\text { Single } \\
\text { center }\end{array}$ & ICU & 84 & $\begin{array}{l}\text { Septic } \\
\text { shock }\end{array}$ & Terlipressin & Noradrenalin \\
\hline $\begin{array}{l}\text { Barzegar } \\
\text { et al, 2017 }\end{array}$ & $\begin{array}{l}\text { Open } \\
\text { label }\end{array}$ & $\begin{array}{l}\text { Single } \\
\text { center }\end{array}$ & ICU & 42 & $\begin{array}{l}\text { Septic } \\
\text { shock }\end{array}$ & Vasopressin & Norepinephrine \\
\hline $\begin{array}{l}\text { Liu et el, } \\
\text { 2018 (26) }\end{array}$ & $\begin{array}{l}\text { Double- } \\
\text { blind }\end{array}$ & $\begin{array}{l}\text { Multi } \\
\text { center }\end{array}$ & ICU & 526 & $\begin{array}{l}\text { Septic } \\
\text { shock }\end{array}$ & Terlipressin & Norepinephrine \\
\hline $\begin{array}{l}\text { Hajjar et } \\
\text { el, 2019 } \\
\text { (23) }\end{array}$ & $\begin{array}{l}\text { Double- } \\
\text { blind }\end{array}$ & $\begin{array}{l}\text { Single } \\
\text { center }\end{array}$ & ICU & 250 & $\begin{array}{l}\text { Cancer } \\
\text { patients } \\
\text { with Septic } \\
\text { shock }\end{array}$ & Vasopressin & Norepinephrine \\
\hline $\begin{array}{l}\text { Laterre et } \\
\text { al, 2019 } \\
\text { (38) }\end{array}$ & $\begin{array}{l}\text { Double- } \\
\text { blind }\end{array}$ & $\begin{array}{l}\text { Multi } \\
\text { center }\end{array}$ & ICU & 828 & $\begin{array}{l}\text { Septic } \\
\text { shock }\end{array}$ & Selepressin & placebo \\
\hline ICU-intensive care unit & & & & & & \\
\hline
\end{tabular}

\section{Risk of bias}

The risk of bias assessment of the eligible trials is illustrated in (Additional file 3) and (Additional file 4). A high risk of performance bias and detection bias was detected in eight studies due to the lack of blinding of either study participants or personnel and outcome assessment $(28,33,34,36,37)$. Additionally, there was a high risk of other potential sources of bias in two studies in Acevedo 2009; the study was only published as an abstract (28), and in Liu 2016 because of the early termination of the trial ahead of schedule (26). Furthermore, although all studies reported adherence to randomization, only (9 studies) described allocation concealment.

\section{Primary outcomes}

Eight RCTs $(23-26,28,35-37)$ assessed the AKI incidence, with a total of 2,094 patients. Norepinephrine was the initial vasopressor in three studies, Whereas In four studies, Vasopressin or Terlipressin were the initial vasopressors in the study group. Two studies evaluated kidney function as a primary outcome with vasopressin infusion $(20,25)$. All the studies allowed additional open-label Norepinephrine if the MAP goal was not achieved. The number of events in the Vasopressin or analogs group was 559 out of 1,058 versus 592 out of 1036 in the control group. The pooled estimate demonstrated a significant reduction in the vasopressin or analogs group without significant heterogeneity. (RR $0.93[0.86,1.00], I^{2}=5 \%$, p-value $\left.=0.04\right)$. (See Fig. 2 for Forest plot evaluating AKI incidence).

Funnel plot visual inspection did not lead to concerns about potential publication bias. (Additional file 5). 
Six RCTs $(20,23,25,36,37,39)$ reported the use of RRT, with a total of 1,555 patients. The number of events in the Vasopressin or analogs group was 223 out of 772 versus 251 out of 741 in the control group.Vasopressin or analogs use was associated with less need for RRT (RR, $-0.05[-0.10,-0.01] l^{2}=0 \%, p$ value $=0.02$ ). (See Fig. 3 for Forest plot evaluating the use of RRT). Funnel plot visual inspection did not lead to concerns about potential publication bias. (Additional file 6). The primary outcomes assessed were evaluated according to the Grading of Recommendations, Assessment, Development, and Evaluation (GRADE) criteria and were judged as moderatequality evidence for both outcomes. (Additional file 7).

\section{Secondary outcomes:}

Three RCTs $(23,35,38)$ with 1,839 participants evaluated days alive free of RRT (28 or 30 days). We observed no significant difference between the two groups (MD $-0.17[-0.90,0.56], I^{2}=0 \%$-value $=0.65$ ). The trial by (Russell and colleagues 2008) carried $64 \%$ of the weight, and after excluding this trial, the conclusion was not altered.

Four RCTs $(31,36,37,39)$ evaluated the change of creatinine value from baseline up to 48 hours, the pooled data did not reach statistical significance and showed substantial heterogeneity (MD $0.05[-0.33,0.42], I^{2}=39 \%$, $p$ value $=81$ ). After performing a sensitivity analysis, we identified the study by (Barzegar and colleagues 2016) as the source of the heterogeneity, and by excluding this trial, the heterogeneity was eliminated $\mathrm{I}^{2}=0 \%$.

Similarly, three RCTs evaluated the urinary output at 48 hours $(33,36,37)$ there was no significant effect between the two groups (MD -13.84 [-50.20, 22.52], I² = 8\%, P-value = 0.46). (See Table 2 for secondary outcomes).

Table 2.Secondary outcomes of Vasopressin or analogs vs. Catecholamines in septic shock.

\begin{tabular}{|llllll|}
\hline Secondary outcome & Studies & Patients (n) & Mean difference [95\% Cl] & Heterogeneity & P value \\
\hline Creatinine level (48h) & 4 & $79 / 65$ & $-0.05[-0.33,0.42]$ & $I^{2}=39 \%$ & $P=0.81$ \\
\hline $\begin{array}{l}\text { Urinary output } \\
\text { (48h) }\end{array}$ & 3 & $58 / 40$ & $-13.84[-50.20,22.52]$ & $I^{2}=8 \%$ & $P=0.46$ \\
$\begin{array}{l}\text { Days alive free of RRT } \\
\text { (28 or } 30 \text { days) }\end{array}$ & 3 & $1071 / 768$ & $-0.17[-0.90,0.56]$ & $I^{2}=0 \%$ & $P=0.65$ \\
Cl- confidence interval; RRT- renal replacement therapy. & & \\
\hline
\end{tabular}

\section{Discussion:}

The findings of this systematic review, and meta-analysis of randomized clinical trials, showed that the administration of Vasopressin or its analogs compared to Catecholamines alone is marginally associated with a significant reduction of AKI incidence and reduces the need for RRT in patients with septic shock (moderatequality evidence). Meanwhile, there was no evidence of a statistically significant effect on RRT- free days, $48 \mathrm{~h}$ urine output, or $48 \mathrm{~h}$ creatinine concentration. 
To our knowledge, this is the first comprehensive meta-analysis on this topic focusing on the renal outcomes solely in septic shock patients. Catecholamines like Norepinephrine reduces urine flow by preferentially binding to a1-adrenoreceptors, mainly located on renal afferent arterioles, contributing to decreased glomerular filtration rate (GFR), creatinine clearance, and urine output $(40,41)$. In contrast, Vasopressin results in increased urine output and improved glomerular filtration rate by binding to V1a receptors on efferent glomerular arterioles without constricting afferent arterioles (41-43).

Although several studies reported an overall higher creatinine clearance or urine output in patients treated with Vasopressin $(20,23,25,30,33)$, we failed to show a significant effect when we pooled the data. We think this could be due to the small sample size affected by the predetermined time point. Hemodynamic changes in the microcirculation and renal microcirculation have been implicated in the pathogenesis of septic AKI and inflammation, but interventions that reduce inflammatory states have not been successful in reducing septic AKI.

However, when Vasopressin is added to Norepinephrine in septic shock, it results in decreased Norepinephrine requirement. Thus, reducing their adverse effect. This reduction trend for the primary outcomes in this review is likely due to vasopressin association with reduced progression to renal failure or loss for patients at risk of kidney injury, therefore, reducing renal replacement therapy requirements (20).

A meta-analysis by (Nedel and colleagues) evaluated the renal outcomes in Distributive shock (septic, postcardiac, post-operative). It concluded with a high risk of bias due to heterogeneity that Vasopressin and its analogs use reduced acute kidney injury incidence and the need for renal replacement therapy in distributive shock but failed to demonstrate a significant effect on septic shock patients when analyzed separately in both outcomes (44).

Two recent systematic reviews with meta-analyses evaluating Vasopressin and its analogs compared to solely using catecholamines found conflicting data on the reduction of 28 days mortality $(22,45)$. Nonetheless, there was a pronounced trend for increased risk of digital ischemia in the vasopressin or analogs group. Terlipressin, a synthetic analog of Vasopressin with a high affinity to V1a receptors, demonstrated in several clinical studies a greater urinary output and creatinine clearance in septic patients with hepatorenal syndrome. However, the evidence was based on a few studies with low quality. Altogether, further, large RCTs are needed to strengthen the evidence of the renal benefit of Vasopressin and Terlipressin use in septic shock.

There are several limitations in our review. First, the AKI definition varied among the included studies. Second, due to the different time points reported in the studies for creatinine level and urinary output, our subgroup analysis of these outcomes was restricted to measure up to 48 hours. Third, the dose and usage were different across trials, and open-label Norepinephrine was allowed if needed to reach the target MAP. Finally, although our search protocol was prespecified before we conducted this review, we did not pre-register our review protocol.

\section{Conclusion:}

Vasopressin and its analogs are associated with a reduced AKI incidence and a lower RRT use rate in septic shock compared to catecholamines. Furthermore, we did not find a significant effect of Vasopressin on the 
number of RRT- free days (up to 28 or 30 days) or in creatinine level and urinary output in 48 hours. However, due to the high mortality associated with S-AKI, large blinded RCTs addressing renal function impairment in septic shock are warranted.

\section{Abbreviations}

AKI- acute kidney injury; RRT- renal replacement therapy; Cl- confidence interval; MAP- mean arterial pressure; 48h- 48 hours; RCTs-randomized control studies GFR- glomerular filtration rate; RR- risk ration; MD- mean difference; MESH-medical subject heading.

\section{Declarations}

\section{Ethics approval and consent to participate}

Not applicable.

\section{Availability of data and material}

The data supporting the conclusion of this article are included within this article and its additional files.

\section{Acknowledgment}

None.

\section{Authors' contributions:}

AEY conceived and designed the study. WH and RY searched the literatures, reviewed the records, and collected the data. AEY and WH were responsible for the statistical analysis. AEY was responsible for data interpretation and created this manuscript. LS read and revised this study carefully from a professional standpoint. The authors read and approved the final manuscript.

\section{Consent for publication}

Not applicable.

\section{Competing interest}

The authors have no conflict of interest to declare.

\section{Funding:}

This work was supported by the National Science Foundation of the Jiangsu Higher Education Institution of China (Grant No. 19KJB320001), and the excellent personnel training program of the Second Affiliated Hospital of Nanjing Medical University (Grant No.789ZYRC202070317). The funding sources had no role in the conducting of this study.

\section{Authors details}


${ }^{1}$ Department of Emergency Medicine, Second Affiliated Hospital of Nanjing Medical

University, Nanjing 210011, Jiangsu, China

2 Department of Critical Care Medicine, Second Affiliated Hospital of Nanjing Medical University, Nanjing 210011, Jiangsu, China

3 Department of Critical Care Medicine, Second Affiliated Hospital of Nanjing Medical University, Nanjing 210011, Jiangsu, China

4 Department of Critical Care Medicine, Second Affiliated Hospital of Nanjing Medical University, Nanjing 210011, Jiangsu, China

\section{References}

1. Vincent JL, Sakr Y, Sprung CL, Ranieri VM, Reinhart K, Gerlach H, et al. Sepsis in European intensive care units: results of the SOAP study. Crit Care Med. 2006;34(2):344-53.

2. Vincent JL, Marshall JC, Namendys-Silva SA, François B, Martin-Loeches I, Lipman J, et al. Assessment of the worldwide burden of critical illness: the intensive care over nations (ICON) audit. Lancet Respir Med. 2014;2(5):380-6.

3. Sakr Y, Jaschinski U, Wittebole X, Szakmany T, Lipman J, Ñamendys-Silva SA, et al. Sepsis in Intensive Care Unit Patients: Worldwide Data From the Intensive Care over Nations Audit. Open Forum Infect Dis. 2018;5(12):ofy313-ofy.

4. Rhodes A, Evans LE, Alhazzani W, Levy MM, Antonelli M, Ferrer R, et al. Surviving Sepsis Campaign: International Guidelines for Management of Sepsis and Septic Shock: 2016. Intensive Care Med. 2017;43(3):304-77.

5. Martin C, Papazian L, Perrin G, Saux P, Gouin F. Norepinephrine or dopamine for the treatment of hyperdynamic septic shock? Chest. 1993;103(6):1826-31.

6. Desjars P, Pinaud M, Potel G, Tasseau F, Touze MD. A reappraisal of norepinephrine therapy in human septic shock. Crit Care Med. 1987;15(2):134-7.

7. Reinhart K, Sakka SG, Meier-Hellmann A. Haemodynamic management of a patient with septic shock. European Journal of Anaesthesiology. 2000;17(1):6-17.

8. Dünser MW, Hasibeder WR. Sympathetic overstimulation during critical illness: adverse effects of adrenergic stress. J Intensive Care Med. 2009;24(5):293-316.

9. Andreis DT, Singer M. Catecholamines for inflammatory shock: a Jekyll-and-Hyde conundrum. Intensive Care Med. 2016;42(9):1387-97.

10. Stolk RF, van der Poll T, Angus DC, van der Hoeven JG, Pickkers P, Kox M. Potentially Inadvertent Immunomodulation: Norepinephrine Use in Sepsis. Am J Respir Crit Care Med. 2016;194(5):550-8.

11. Jentzer JC, Vallabhajosyula S, Khanna AK, Chawla LS, Busse LW, Kashani KB. Management of Refractory Vasodilatory Shock. Chest. 2018;154(2):416-26.

12. De Backer D, Biston P, Devriendt J, Madl C, Chochrad D, Aldecoa C, et al. Comparison of dopamine and norepinephrine in the treatment of shock. N Engl J Med. 2010;362(9):779-89. 
13. Landry DW, Levin HR, Gallant EM, Ashton RC, Jr., Seo S, D'Alessandro D, et al. Vasopressin deficiency contributes to the vasodilation of septic shock. Circulation. 1997;95(5):1122-5.

14. Sood M, Mandelzweig K, Rigatto C, Tangri N, Komenda P, Martinka G, et al. Non-pulmonary infections but not specific pathogens are associated with increased risk of AKI in septic shock. Intensive Care Med. 2014;40(8):1080-8.

15. Suh SH, Kim CS, Choi JS, Bae EH, Ma SK, Kim SW. Acute kidney injury in patients with sepsis and septic shock: risk factors and clinical outcomes. Yonsei Med J. 2013;54(4):965-72.

16. Bagshaw SM, Uchino S, Bellomo R, Morimatsu H, Morgera S, Schetz M, et al. Septic acute kidney injury in critically ill patients: clinical characteristics and outcomes. Clin J Am Soc Nephrol. 2007;2(3):431-9.

17. Venot M, Weis L, Clec'h C, Darmon M, Allaouchiche B, Goldgran-Tolédano D, et al. Acute Kidney Injury in Severe Sepsis and Septic Shock in Patients with and without Diabetes Mellitus: A Multicenter Study. PLoS One. 2015;10(5):e0127411.

18. Kellum JA, Chawla LS, Keener C, Singbartl K, Palevsky PM, Pike FL, et al. The Effects of Alternative Resuscitation Strategies on Acute Kidney Injury in Patients with Septic Shock. Am J Respir Crit Care Med. 2016;193(3):281-7.

19. Choudhury A, Kedarisetty CK, Vashishtha C, Saini D, Kumar S, Maiwall R, et al. A randomized trial comparing terlipressin and noradrenaline in patients with cirrhosis and septic shock. Liver Int. 2017;37(4):552-61.

20. Gordon AC, Russell JA, Walley KR, Singer J, Ayers D, Storms MM, et al. The effects of vasopressin on acute kidney injury in septic shock. Intensive Care Medicine. 2010;36(1):83-91.

21. Holmes CL, Walley KR, Chittock DR, Lehman T, Russell JA. The effects of vasopressin on hemodynamics and renal function in severe septic shock: a case series. Intensive Care Med. 2001;27(8):1416-21.

22. Zhong L, Ji XW, Wang HL, Zhao GM, Zhou Q, Xie B. Non-catecholamine vasopressors in the treatment of adult patients with septic shock-evidence from meta-analysis and trial sequential analysis of randomized clinical trials. J Intensive Care. 2020;8(1):83.

23. Hajjar LA, Zambolim C, Belletti A, de Almeida JP, Gordon AC, Oliveira G, et al. Vasopressin Versus Norepinephrine for the Management of Septic Shock in Cancer Patients: The VANCS II Randomized Clinical Trial. Crit Care Med. 2019;47(12):1743-50.

24. Xiao X, Zhang J, Wang Y, Zhou J, Zhu Y, Jiang D, et al. Effects of terlipressin on patients with sepsis via improving tissue blood flow. J Surg Res. 2016;200(1):274-82.

25. Gordon AC, Mason AJ, Thirunavukkarasu N, Perkins GD, Cecconi M, Cepkova M, et al. Effect of Early Vasopressin vs Norepinephrine on Kidney Failure in Patients With Septic Shock: The VANISH Randomized Clinical Trial. Jama. 2016;316(5):509-18.

26. Liu ZM, Chen J, Kou Q, Lin Q, Huang X, Tang Z, et al. Terlipressin versus norepinephrine as infusion in patients with septic shock: a multicentre, randomised, double-blinded trial. Intensive Care Med. 2018;44(11):1816-25.

27. Page MJ, McKenzie JE, Bossuyt PM, Boutron I, Hoffmann TC, Mulrow CD, et al. The PRISMA 2020 statement: an updated guideline for reporting systematic reviews. BMJ. 2021;372:n71.

28. Acevedo J, Fernandez J, Escorsell A, Mas A, Gines P, Arroyo V. 174 clinical efficacy and safety of terlipressin administration in cirrhotic patients with septic shock. Journal of Hepatology. 2009(50):S73. 
29. Malay MB, Ashton RC, Jr., Landry DW, Townsend RN. Low-dose vasopressin in the treatment of vasodilatory septic shock. J Trauma. 1999;47(4):699-703; discussion -5.

30. Patel BM, Chittock DR, Russell JA, Walley KR. Beneficial effects of short-term vasopressin infusion during severe septic shock. Anesthesiology. 2002;96(3):576-82.

31. Dünser MW, Mayr AJ, Ulmer H, Knotzer H, Sumann G, Pajk W, et al. Arginine vasopressin in advanced vasodilatory shock: a prospective, randomized, controlled study. Circulation. 2003;107(18):2313-9.

32. Albanèse J, Leone M, Delmas A, Martin C. Terlipressin or norepinephrine in hyperdynamic septic shock: a prospective, randomized study. Crit Care Med. 2005;33(9):1897-902.

33. Lauzier F, Lévy B, Lamarre P, Lesur O. Vasopressin or norepinephrine in early hyperdynamic septic shock: a randomized clinical trial. Intensive Care Med. 2006;32(11):1782-9.

34. Morelli A, Ertmer C, Lange M, Dünser M, Rehberg S, Van Aken H, et al. Effects of short-term simultaneous infusion of dobutamine and terlipressin in patients with septic shock: the DOBUPRESS study. Br J Anaesth. 2008;100(4):494-503.

35. Russell JA, Walley KR, Singer J, Gordon AC, Hébert PC, Cooper DJ, et al. Vasopressin versus norepinephrine infusion in patients with septic shock. N Engl J Med. 2008;358(9):877-87.

36. Morelli A, Ertmer C, Rehberg S, Lange M, Orecchioni A, Cecchini V, et al. Continuous terlipressin versus vasopressin infusion in septic shock (TERLIVAP): a randomized, controlled pilot study. Crit Care. 2009;13(4):R130.

37. Barzegar E, Ahmadi A, Mousavi S, Nouri M, Mojtahedzadeh M. The Therapeutic Role of Vasopressin on Improving Lactate Clearance During and After Vasogenic Shock: Microcirculation, Is It The Black Box? Acta Med Iran. 2016;54(1):15-23.

38. Laterre PF, Berry SM, Blemings A, Carlsen JE, François B, Graves T, et al. Effect of Selepressin vs Placebo on Ventilator- and Vasopressor-Free Days in Patients With Septic Shock: The SEPSIS-ACT Randomized Clinical Trial. Jama. 2019;322(15):1476-85.

39. Barzegar E, Nouri M, Mousavi S, Ahmadi A, Mojtahedzadeh M. Vasopressin in Septic Shock; Assessment of Sepsis Biomarkers: A Randomized, Controlled Trial. Indian J Crit Care Med. 2017;21(9):578-84.

40. Bomzon L, Rosendorff C. Renovascular resistance and noradrenaline. Am J Physiol. 1975;229(6):1649-53.

41. Edwards RM, Trizna W, Kinter LB. Renal microvascular effects of vasopressin and vasopressin antagonists. Am J Physiol. 1989;256(2 Pt 2):F274-8.

42. Sparapani S, Millet-Boureima C, Oliver J, Mu K, Hadavi P, Kalostian T, et al. The Biology of Vasopressin. Biomedicines. 2021;9(1):89.

43. Jung HJ, Kwon TH. Molecular mechanisms regulating aquaporin-2 in kidney collecting duct. Am J Physiol Renal Physiol. 2016;311(6):F1318-f28.

44. Nedel WL, Rech TH, Ribeiro RA, Pellegrini JAS, Moraes RB. Renal Outcomes of Vasopressin and Its Analogs in Distributive Shock: A Systematic Review and Meta-Analysis of Randomized Trials. Critical Care Medicine. 2019;47(1):e44-e51.

45. Yao R-Q, Xia D-M, Wang L-X, Wu G-S, Zhu Y-B, Zhao H-Q, et al. Clinical Efficiency of Vasopressin or Its Analogs in Comparison With Catecholamines Alone on Patients With Septic Shock: A Systematic Review and Meta-Analysis. Frontiers in pharmacology. 2020;11:563-. 


\section{Figure 1.}

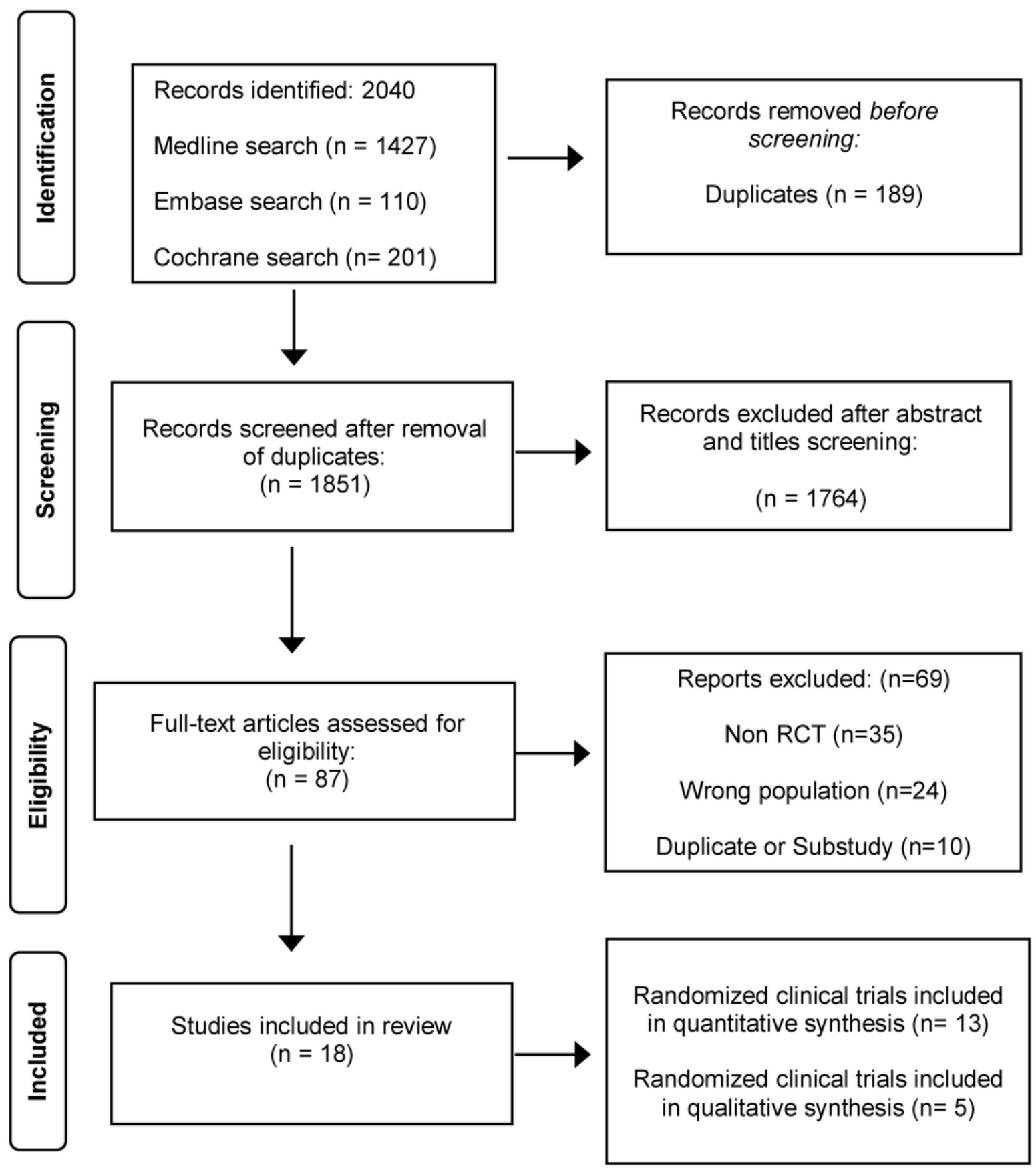

Figure 1

Flowchart for study selection process 


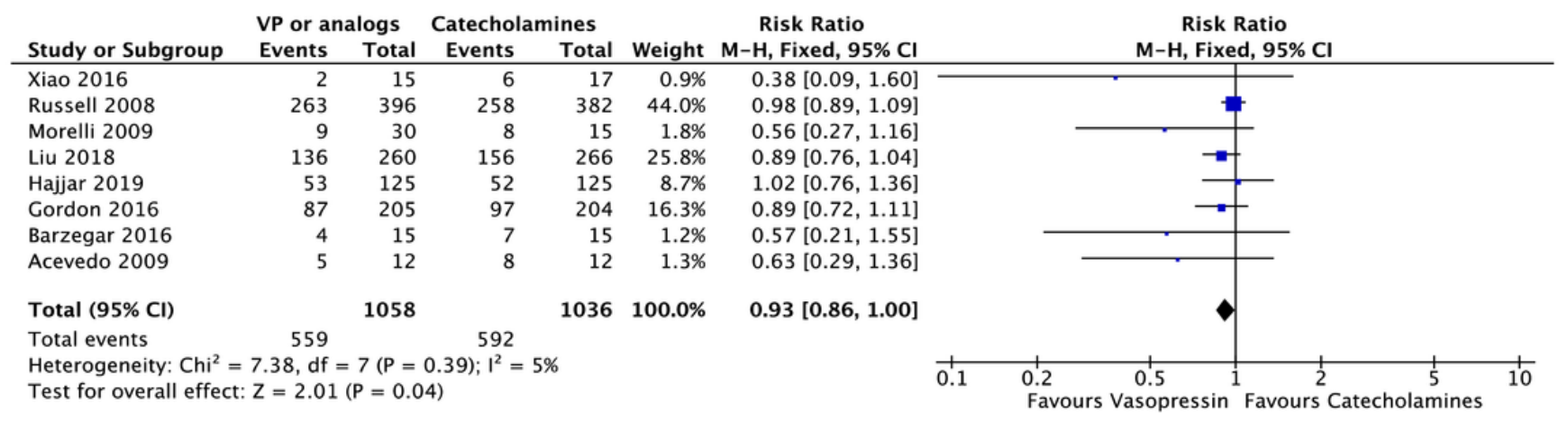

\section{Figure 2}

Forest plot of trials evaluating the incidence of acute kidney injury in vasopressin (VP) or analogs group compared to catecholamines group in septic shock patients. $\mathrm{M}-\mathrm{H}=$ Mantel-Haenszel; $\mathrm{Cl}=$ confidence interval; $\mathrm{df}$ $=$ degrees of freedom.

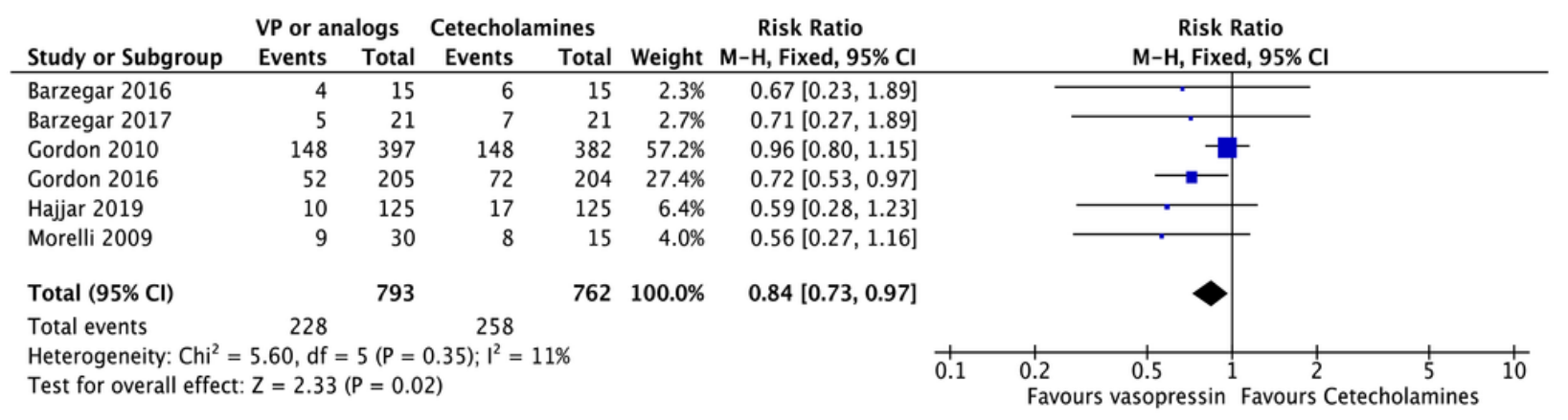

\section{Figure 3}

Forest plot of trials evaluating the need for renal replacement therapy in vasopressin (VP) or analogs group compared to catecholamines group in septic shock patients. $\mathrm{M}-\mathrm{H}=$ Mantel-Haenszel; $\mathrm{Cl}=$ confidence interval; $\mathrm{df}$ $=$ degrees of freedom

\section{Supplementary Files}

This is a list of supplementary files associated with this preprint. Click to download.

- Additionalfile1PubMedsearchstrategy1.docx 
- Additionalfile2Studies.docx

- Additionalfile3..eps

- Additionalfile4.eps

- Additionalfile5.eps

- Additionalfile6FunnelplotforRRTuse.eps

- Additionalfile7.GradeEvidence.docx 